Article

\title{
Antibacterial/Antiviral Property and Mechanism of Dual-Functional Quaternized Pyridinium-type Copolymer
}

\author{
Yan Xue ${ }^{1,2}$ and Huining Xiao ${ }^{2, *}$ \\ Received: 12 October 2015 ; Accepted: 3 November 2015 ; Published: 11 November 2015 \\ Academic Editor: Jianxun Ding \\ 1 School of Chemistry and Chemical Engineering, Oil \& Gas Field Applied Chemistry Key Laboratory of \\ Sichuan Province Southwest Petroleum University, Chengdu 610500, China; yxue@swpu.edu.cn \\ 2 Department of Chemical Engineering, University of New Brunswick, Fredericton, NB E3B 5A3, Canada \\ * Correspondence: hxiao@unb.ca; Tel.: +1-506-453-3532; Fax: +1-506-453-3591
}

\begin{abstract}
Due to the massive outbreaks of pathogen-caused diseases and the increase of drug-resistant pathogens, there is a particular interest in the development of novel disinfection agents with broad-spectrum antipathogenic activity. In the present study, water-soluble pyridinium-type polyvinylpyrrolidones with different counter anions were prepared. Structural characterization was conducted via ${ }^{13} \mathrm{C}-{ }^{1} \mathrm{H}$ heteronuclear single quantum coherence spectroscopy, static light scattering, UV spectrometry and apparent charge density. The influence of counter anion and polymer compositions on the antibacterial activity was studied against Staphylococcus aureus and Escherichia coli. Atomic force microscopy (AFM) was applied for tracking the morphological alterations in bacterial cells induced by prepared polycations. It was found that the exposure of bacteria to the polycations resulted in the destruction of cell membranes and the leakage of cytoplasm. The antiviral activity of pyridinium-type polycations against enveloped influenza virus was evaluated via a plaque assay. The action mode against enveloped virus was depicted to rationalize the antiviral mechanism.
\end{abstract}

Keywords: pyridinium; polycation; antimicrobial polymer; antiviral; enveloped virus

\section{Introduction}

With environmental pollution becoming serious, various disease outbreaks caused by some pathogens are threatening human life. Therefore, the control of the growth of pathogens, including viruses, bacteria and fungi, is a severe task for the survival of human beings. For inhibiting pathogen infections, a variety of disinfection agents are produced. Among them, antimicrobial polymers have become increasingly important as an alternative to existing biocides. Compared with conventional low-molecular-weight biocides, antimicrobial polymers have advantages such as enhanced antimicrobial activity, efficiency and selectivity, reduced residual toxicity and microbe resistance, and prolonged stability [1-3]. Traditionally, incorporation of the antimicrobial agents into polymers is achieved by coating drug agents on the surface of polymers or physically entrapping the active agent within a polymer matrix [4]. However, majority of the antimicrobial agents steadily permeates out from the polymer matrices, giving rise to poisonous influences on the human body [5,6]. Polymerization of monomers possessing antimicrobial activity would eliminate the biocide-releasing problem, presenting long-term durability and environmentally friendly performance $[7,8]$.

At present, most of the antimicrobial polymers only target on killing or inactivating bacteria. Their inhibition effects on virus, another kind of pathogen widely existing in nature, usually remain 
minimal. In recent years, however, the outbreaks of MERS (Middle East Respiratory Syndrome), Ebola virus, SARS (Severe Acute Respiratory Syndromes), avian influenza, hoof-and-mouth disease and other pandemic diseases caused by viruses induced a vital impact on human health and social economy. Therefore, the development of novel disinfectant materials containing both bactericidal and virucidal activities has become imperative. Haldar et al. [9] studied the antibacterial and antiviral activities of $N, N$-dodecyl methylpolyethylenimines (PEIs) by coating glass slides with branched and liner PEIs and contacting influenza virus, Staphylococcus aureus (S. aureus) and Escherichia coli (E. coli). They found that certain hydrophobic polycations can deactivate not only Gram-positive and Gram-negative bacteria but also enveloped viruses.

In the study of the antimicrobial/antiviral activity of cross-linked poly(N-benzyl-4vinylpyridinium halide) (PBVP) in water treatment and removal of microorganisms from air, Kawabata et al. $[10,11]$ found that this insoluble pyridinium-type polymer can capture bacteria, yeasts, spores of fungi, poliovirus and bacteriophage T4 upon contacting with them. Cross-linked PBVP removed viruses from water even more effectively than the case of bacteria [12]. Previous studies showed that grafting quaternary pyridium polymer on surfaces conferred surfaces with high-efficient antibacterial properties against both airborne and waterborne bacteria [13-16]. Insoluble pyridinium-type polymers can capture bacteria alive, while soluble pyridinium polymers can kill bacteria by interacting with and disrupting bacterial cell membranes $[17,18]$. Sambhy et al. [19] prepared two series of amphiphilic pyridinium-methacrylate copolymers with different spatial positions of the positive charge and the alkyl tail. By mimicking the membrane-disrupting properties of natural antimicrobial peptides, the amphiphilic pyridinium-type copolymers showed high biocidal activity towards bacteria.

Based on the prior studies, pyridinium-type polymer has been proved that at insoluble state it possesses great ability to capture, coagulate and sedimentate bacteria and viruses, and at soluble state it can interact with the microbial cell wall, destabilize the cytoplasmic membrane and lead to the death of bacteria. We reasoned that the influenza virus, a class of enveloped virus, can also be inactivated by soluble pyridinium-type polymers via damaging the outside lipid envelope. To lower the cytotoxicity and enhance the water solubility, the monomer $N$-vinyl pyrrolidone (NVP) was selected to copolymerize with quaternized pyridinium. Polyvinylpyrrolidone (PVP) has non-toxicity, good biocompatibility and excellent wetting properties and has been used in a wide variety of applications in pharmacy, cosmetics and industrial production [20,21]. Rendering PVP bactericidal and virucidal can expand its applications significantly, such as disinfectant coatings, water purification filters, specific additives for papermaking, water treatment, binders in pharmaceutical tablets, and other products requiring a high degree of safety for the civilian population.

In this work, water-soluble pyridinium-type copolymers that possess both antibacterial and antiviral activities were synthesized and characterized. Their bactericidal and virucidal properties were studied by determining the minimum inhibition concentration (MIC) against S. aureus and E. coli and virus killing efficiency against influenza virus, respectively. The relationships between the composition, counter anion type and their antipathogenic activities were also elucidated.

\section{Experimental Section}

\subsection{Materials}

4-Vinylpyridine (4VP) and N-vinyl pyrrolidone (NVP) from Sigma-Aldrich (St. Louis, MO, USA) were distilled under vacuum before polymerization. 2,2'-Azobis(2-methylpropionamidine) dihydrochloride (AIBA), benzyl chloride, benzyl bromide, ethanol, diethyl ether, dimethylformamide (DMF), chloroform- $d\left(\mathrm{CDCl}_{3}\right)$, deuterium oxide $\left(\mathrm{D}_{2} \mathrm{O}\right)$, agar and $\mathrm{LB}$ broth (all from Sigma-Aldrich) were used without further purification. Poly(4-vinylpyridine) (P4VP) was prepared via radical polymerization using DMF as the solvent and AIBA as the initiator ( $0.8 \%$ of monomer mass). 
Spectra/Pro cellulose dialysis membranes (molecular weight cut off, MWCO = $1000 \mathrm{Da}$, Krackeler Scientific, Albany, NY, USA) were used to purify the products.

\subsection{Test Microorganisms}

For the antibacterial assessment, colonies of Gram-positive S. aureus (ATCC 6538) obtained from East China University of Science and Technology (Shanghai, China) and Gram-negative E. coli (ATCC 11229) obtained from Canadian Research Institute for Food Safety (CRIFS, Guelph, $\mathrm{ON}$, Canada) at the University of Guelph were grown and maintained in nutrient broth prior to test. For the antiviral test, Madin-Darby canine kidney (MDCK) cells, provided by IWK Health Centre at the Dalhousie University (Halifax, NS, Canada), were grown at $37{ }^{\circ} \mathrm{C}$ in Dulbecco's Modified Eagle Medium (DMEM, Thermo Fisher Scientific, Waltham, MA, USA) supplemented with $10 \%$ heat-inactivated fetal bovine serum (FBS, Thermo Fisher Scientific, Waltham, MA, USA). The enveloped stain utilized in the test, influenza virus (A/PR8/8/34), were also provided by IWK Health Centre at the Dalhousie University (Halifax, NS, Canada).

\subsection{Characterizations}

\subsubsection{Fourier Transform Infrared (FTIR) Spectroscopy}

FTIR spectra of P4VP, poly(4VP-co-NVP) and poly(BVPC-co-NVP) were recorded by a Bruker VECTOR-22 spectrophotometer (Bruker Optics Ltd., Billerica, MA, USA) using the KBr pellet method at room temperature.

\subsubsection{Nuclear Magnetic Resonance (NMR) Spectroscopy}

The ${ }^{1} \mathrm{H}$ NMR spectra were recorded in $\mathrm{CDCl}_{3}$ or $\mathrm{D}_{2} \mathrm{O}$ at $25^{\circ} \mathrm{C}$ using an Oxford 300 spectrometer (Oxford, UK) operating at $300.15 \mathrm{MHz} .{ }^{13} \mathrm{C}$ NMR and ${ }^{13} \mathrm{C}-{ }^{1} \mathrm{H}$ heteronuclear single quantum coherence $\left({ }^{13} \mathrm{C}-{ }^{1} \mathrm{H}\right.$ HSQC $)$ spectra of quaternized copolymer were obtained using an Oxford 400 spectrometer (Oxford, UK) operating at $100.55 \mathrm{MHz}$ for carbons and $399.96 \mathrm{MHz}$ for protons in $\mathrm{D}_{2} \mathrm{O}$ at room temperature.

\subsubsection{Static Light Scattering (SLS)}

The molecular weight of prepared copolymers was determined using a Debye Plot method, which is absolute and uses the intensity of light scattered at $90^{\circ}$ (SLS). A 90PDP Brookhaven spectrophotometer (Long Island, NY, USA) equipped with a BI-APD avalanche photodiode was employed for the measurements at room temperature. The light source was a $656 \mathrm{~nm}, 35 \mathrm{~mW}$ diode laser. HPLC-grade toluene (refractive index $=1.4889$, Rayleigh ratio $=1.137 \times 10^{-08}$ ) was used as the calibration liquid, and deionized water was used as the normalization solvent. A BI-DNDC Brookhaven differential refractometer $\left(\lambda_{0}=620 \mathrm{~nm}\right.$, Long Island, NY, USA) was used to determine the specific refractive index increments, $\mathrm{d} n / \mathrm{d} c$. Prior to testing, polymer solutions were filtered through Nylon Cameo filter-syringes (St. Louis, MO, USA) with a pore size of $0.45 \mu \mathrm{m}$ to remove dust particles. The data analysis was conducted using a Brookhaven's 90Plus Debye plot analysis software (Long Island, NY, USA).

\subsubsection{Apparent Charge Density}

Apparent charge density of quaternized poly(4VP-co-NVP) was determined via colloidal titration using a Particle Charge Detector Mütek PCD 03 (Herrsching, Germany) at $25{ }^{\circ} \mathrm{C}$. One milliliter of $0.5 \mathrm{~g} / \mathrm{L}$ polymer solution was added into the sample cell containing $9 \mathrm{~mL}$ of water. The solution was titrated with a standard anionic polyelectrolyte (potassium polyvinyl sulfate (PVSK) solution) (concentration $=0.385 \mathrm{mN}$ ). The charge densities of the cationic copolymers were calculated from the volume of the anionic polymer solution required to reach the end point over the titration. Three repeats were conducted to acquire an average value for each sample. 


\subsubsection{UV Spectrophotometry}

Compositions of poly(4VP-co-NVP) were determined via an UV spectrophotometer (Genesys 10; Thermo Electron Corporation, Marietta, OH, USA) using ethanol as the solvent, in accordance with the maximum absorbance peak of 4-vinylpyridine at $255 \mathrm{~nm}$. According to the Beer-Lambert Law, $4 \mathrm{VP}$ content could be determined via a calibration curve.

\subsubsection{Atomic Force Microscopy (AFM) Analysis}

AFM technology was utilized to visualize the morphological changes of E. coli prior to and after treated with prepared polycations in a tapping mode. AFM imaging was performed with a Nanoscope IIIa (Veeco Instruments Inc., Santa Barbara, CA, USA) using an etched silicon probe (NP-S20, Veeco Instruments) with a scan rate of $0.3 \mathrm{~Hz}$. The bacterial samples were prepared at room temperature as follows. E. coli cells in LB broth were separated by centrifuging bacterial suspension $\left(10^{8} \mathrm{CFU} / \mathrm{mL}\right)$ at $5000 \mathrm{rpm}$ for $2 \mathrm{~min}$, and washed with sterile DD water twice and re-dispersed in DD water $\left(10^{6} \mathrm{CFU} / \mathrm{mL}\right)$ as fresh E. coli. Treated E. coli suspensions were prepared by mixing fresh E. coli with quaternized poly(4VP-co-NVP) solution (poly(BVPC-co-NVP) $1,50 \mathrm{ppm}$ ) and shaking for $30 \mathrm{~s}$. After 3 and $20 \mathrm{~min}$, the mixtures were centrifuged at $5000 \mathrm{rpm}$ for $2 \mathrm{~min}$. Then, the supernatant was removed and a same amount of sterile DD water was supplemented. The treated E. coli cells were washed three times for complete removal of PBS and polymer residues. For AFM imaging, fresh and treated E. coli samples were dropped onto silicon plates (Universitywafer, South Boston, MA, USA) and dried in a fume hood.

\subsection{Copolymerization of $4 V P$ and $N V P$}

A typical procedure of the copolymerization of 4VP and NVP is described as follows: $9.62 \mathrm{~mL}$ $(0.09 \mathrm{~mol})$ of NVP and $0.08 \mathrm{~g}$ of AIBA dissolved in $45.0 \mathrm{~mL}$ of ethanol were placed in a three-necked flask equipped with a reflux condenser and a nitrogen inlet. The stirred solution was heated to $60^{\circ} \mathrm{C}$ for $10 \mathrm{~h}$. The solution of $1.14 \mathrm{~mL}(0.01 \mathrm{~mol})$ of $4 \mathrm{VP}$ in $5.0 \mathrm{~mL}$ of ethanol was added dropwise into the flask under nitrogen flow during the process of polymerization. After reaction, the mixture was poured into diethyl ether to precipitate the copolymer. The crude product was purified by three times of dissolution in ethanol and reprecipitation in ether. The product filtered was dried at $40{ }^{\circ} \mathrm{C}$ under vacuum. (Yield: 91.3\%)

\subsection{Quaternization of Poly(4VP-co-NVP) via N-Alkylation}

Poly(4VP-co-NVP) was quaternized with benzyl halide as follows. The amount of fed benzyl halide was set to be equimolar to that of $4 \mathrm{VP}$ in the copolymer. Five grams of poly(4VP-co-NVP) was placed in a flask containing $40 \mathrm{~mL}$ of DMF. After the copolymer dissolved, prescribed amount of benzyl halide was added dropwise with stirring. The mixture was heated to $80^{\circ} \mathrm{C}$ and reacted for $8 \mathrm{~h}$. Afterwards, the solution was dialyzed against distilled water over 2 days and dried in vacuum. The quaternized poly(4VP-co-NVP) by benzyl chloride and benzyl bromide were respectively remarked as poly(BVPC-co-NVP) and poly(BVPB-co-NVP) in the following sections.

\subsection{Antibacterial Assessment}

The antibacterial properties of the quaternary pyridinium-type polymers were tested against Gram-positive S. aureus (ATCC 6538) and Gram-negative E. coli (ATCC 11229). The bacteria were grown and maintained in LB broth. The minimum inhibition concentration (MIC), also called broth dilution, is one of the popular antimicrobial criterions used for investigating the antimicrobial compounds. This method was used to determine the minimum concentration of polymers required to deactivate the bacteria in solutions [22]. Briefly, fresh cultured bacterial colonies were diluted with LB broth to $10^{6} \mathrm{CFU} / \mathrm{mL}$. Two-fold serial solutions of the tested samples were prepared with sterile LB broth in glass tubes. The final concentrations of the polymer solution ranged from 500 to $1.75 \mathrm{ppm}$. 
Then, $0.2 \mathrm{~mL}$ of bacterial suspension $\left(10^{6} \mathrm{CFU} / \mathrm{mL}\right)$ was added to the polymer/broth solutions, and seeded tubes were incubated at $37^{\circ} \mathrm{C}$ for $24 \mathrm{~h}$. The MIC was interpreted as the lowest concentration that could inhibit the visible growth of bacteria compared to that of the control samples. All the experiments were performed in triplicate and the mean values were calculated.

\subsection{Antiviral Assessment}

The influenza virus plaque assay was performed on MDCK cells to evaluate the antiviral activity of the quaternized pyridinium-type copolymer. Poly(BVPC-co-NVP $)_{1}$ and poly(BVPB-co-NVP $)_{1}$ were tested at three concentrations of 10,25 and $50 \mu \mathrm{g} / \mathrm{mL}$ (polymers were dissolved in phosphate buffer saline, PBS), respectively. The assay was performed as follows: 750,000 MDCK cells in $3 \mathrm{~mL}$ DMEM with 10\% FBS were seeded per well using six-well cell culture plates. The next day cell culture supernatant was removed and replaced with $2 \mathrm{~mL}$ media containing influenza virus with test polymer PBS solution. After $2 \mathrm{~h}$ of incubation at $37{ }^{\circ} \mathrm{C}$ with $5 \% \mathrm{CO}_{2}$, cell culture supernatant was removed and replaced by $2 \mathrm{~mL}$ of $0.5 \%$ agarose in DMEM with $5 \%$ heat-inactivated FBS. When agarose overlay had set, cells were incubated at $37^{\circ} \mathrm{C}$ for 3 days and then stained by $0.03 \%$ neutral red solution. Afterwards, plates were washed with distilled water to remove excess dye and plaques were counted. This dye can only be taken up by living cells, and not by dead cells, resulting in only the living cells stained red. Each test was performed in triplicate.

The virucidal efficiency (\%) was determined as follows:

$$
\text { Virucidal efficiency }(\%)=\left(1-\frac{N}{M}\right) \times 100 \%
$$

where $M$ and $N$ are the numbers of the plaques detected from the control and treated samples, respectively.

\section{Results and Discussion}

\subsection{Copolymerization of $4 V P$ and NVP}

The overall route of the synthesis of poly(4VP-co-NVP) and quaternization is schematically shown in Scheme 1:

a.

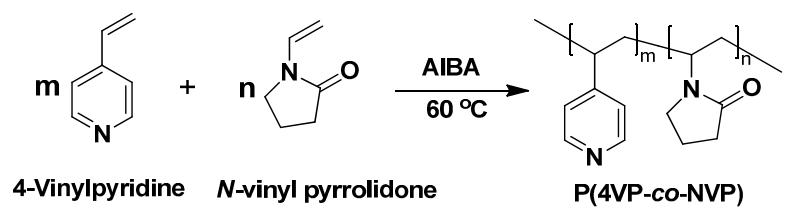

b.

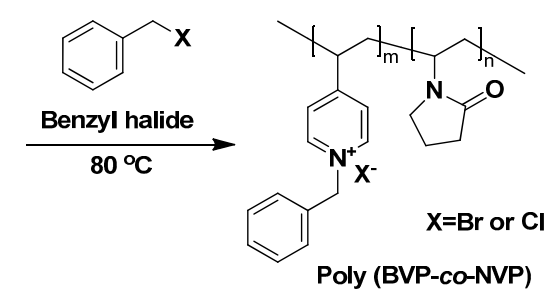

Scheme 1. Synthesis route of (a) poly(4VP-co-NVP) and (b) poly(BVP-co-NVP).

The reactivity ratios of comonomers $4 \mathrm{VP}$ and NVP are $r_{4 \mathrm{vp}}=9.06$ and $r_{\mathrm{nvp}}=0.05[23,24]$, respectively. The significant difference of reactivities can hinder the less active monomer NVP from participating at the early stage of copolymerization. Therefore, the copolymerization was carried out by dropwise adding the active monomer 4VP into NVP solution to obtain ideal compositions. 
Figure 1a,b illustrates the FTIR spectra of P4VP and poly(4VP-co-NVP). The characteristic vibrations of pyridine ring were present at 1598, 1556, 1461 and $1416 \mathrm{~cm}^{-1}$ in Figure 1a. After copolymerization, a broad band of $\mathrm{C}=\mathrm{O}$ from the pyrrolidone ring was observed at $1650 \mathrm{~cm}^{-1}$ (Figure $1 \mathrm{~b}$ ) due to the strong coupled effect with $\mathrm{C}-\mathrm{N}$. The peak at $3204 \mathrm{~cm}^{-1}$ is assigned to the first overtone of the $\mathrm{C}=\mathrm{O}$ vibration. The band at $1290 \mathrm{~cm}^{-1}$ was attributed to the stretching vibration of $\mathrm{C}-\mathrm{N}$, while the broad line at $3550 \mathrm{~cm}^{-1}$ was assigned to the $\mathrm{O}-\mathrm{H}$ stretch region of hydrogen-bonded water.

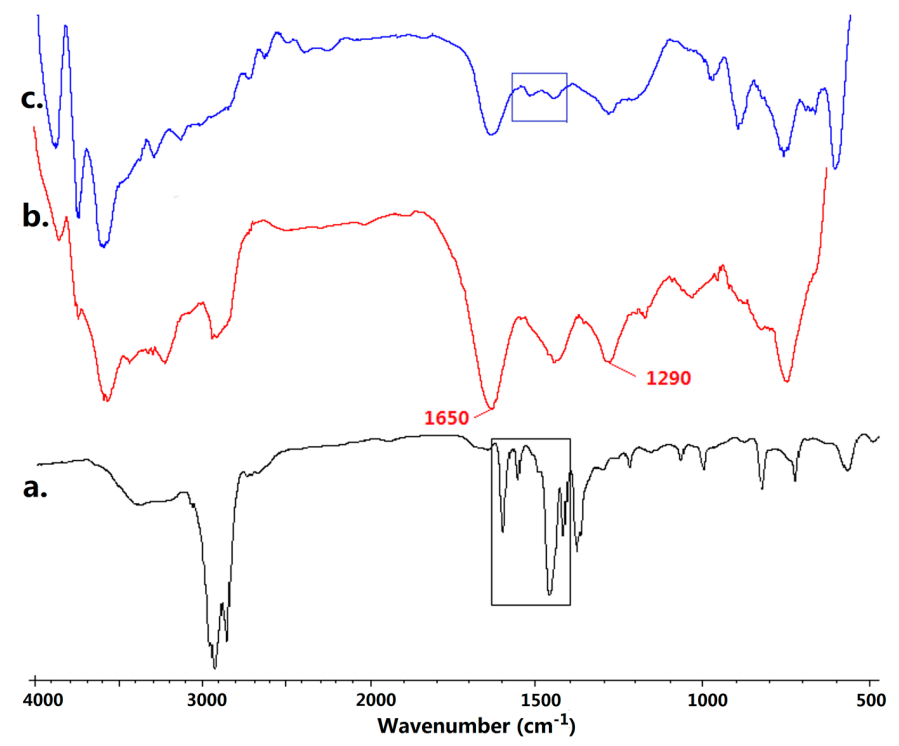

Figure 1. FTIR spectra of (a) poly(4-vinyl pyridine); (b) poly(4VP-co-NVP); and (c) poly(BVPCco-NVP).

The ${ }^{1} \mathrm{H}$ NMR spectrum of poly $(4 \mathrm{VP}-\mathrm{co}-\mathrm{NVP}$ ) (molar ratio of $4 \mathrm{VP}: \mathrm{NVP}=50: 50$ ) is assigned in Figure 2b. Spectrum of (a) in Figure 2 is the ${ }^{1} \mathrm{H}$ NMR spectrum of P4VP. Proton peaks present at $\delta=8.4$ and $6.8 \mathrm{ppm}$ corresponded to the $\alpha$ - and $\beta$-protons of pyridinium group in $4 \mathrm{VP}$, respectively. The broadening of the NMR signal belonging to the $\beta$-protons might be due to the various microenvironments where pyridines were placed after copolymerization with pyrrolidone. Peaks at $\delta=3.6,2.6$ and $2.2 \mathrm{ppm}$ belonged to the methylene protons of pyrrolidone group in NVP. Both the FTIR and ${ }^{1} \mathrm{H}$ NMR spectra indicated that the copolymerization of $4 \mathrm{VP}$ and NVP was accomplished successfully.

Various monomer feed ratios were attempted to optimize the antimicrobial activity. The actual content of pyridine unit in the copolymer could be quantified via ${ }^{1} \mathrm{H}$ NMR and UV measurements. As shown in Table 1, both the ${ }^{1} \mathrm{H}$ NMR and UV measurements indicated the actual pyridine content in the copolymer was close to the designed value. The results verified that the conversion rates of the two monomers were essentially identical through the method of dropwise adding active monomer.

Table 1. Reaction parameter for the copolymerization of $4 \mathrm{VP}\left(\mathrm{M}_{1}\right)$ and $\mathrm{NVP}\left(\mathrm{M}_{2}\right)$ and copolymer composition.

\begin{tabular}{|c|c|c|c|}
\hline Sample & Feed molar ratio of $4 \mathrm{VP}(\mathrm{mol} \%)$ & $4 \mathrm{VP}$ content ${ }^{\mathrm{a}}(\mathrm{mol} \%)$ & $4 \mathrm{VP}$ content ${ }^{\mathrm{b}}(\mathrm{mol} \%)$ \\
\hline P4VP & 100 & 100 & 100 \\
\hline Poly $(4 V P-c o-N V P)_{1}$ & 50 & 52.8 & 55.9 \\
\hline Poly $(4 V P-c o-N V P)_{2}$ & 30 & 34.5 & 35.3 \\
\hline Poly $(4 V P-c o-N V P)_{3}$ & 10 & 11.6 & 11.2 \\
\hline
\end{tabular}

a Determined by ${ }^{1} \mathrm{H}$ NMR spectroscopy in $\mathrm{CDCl}_{3} ;{ }^{\mathrm{b}}$ Determined by UV spectrophotometer at $255 \mathrm{~nm}$. 


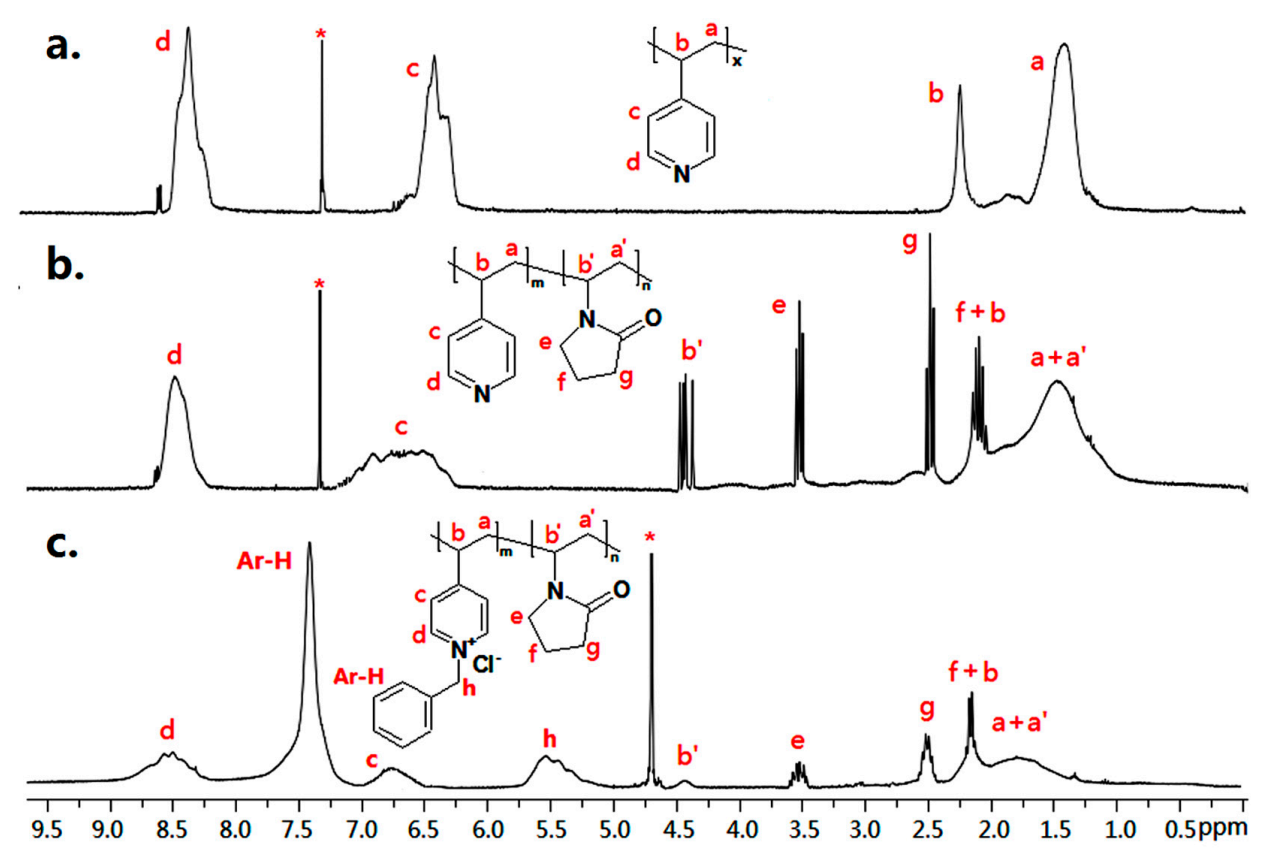

Figure 2. ${ }^{1} \mathrm{H}$ NMR spectra of (a) poly(4-vinyl pyridine) in $\mathrm{CDCl}_{3}$; (b) poly(4VP-co-NVP) in $\mathrm{CDCl}_{3}$; and (c) poly (BVPC-co-NVP) in $\mathrm{D}_{2} \mathrm{O}$. The signals originating from solvents are marked with asterisks.

\subsection{Quternization of Poly(4VP-co-NVP)}

Quaternary pyridinium-type copolymers were prepared via $N$-alkylation using benzyl chloride and benzyl bromide. Figure 1c illustrates the FTIR spectrum of quaternized copolymer poly(BVPC-co-NVP). In the range of 1600 to $1450 \mathrm{~cm}^{-1}$, aromatic $\mathrm{C}=\mathrm{C}$ vibration were found, which was attributed to the benzene ring of benzyl chloride. A new peak at $3100 \mathrm{~cm}^{-1}$ was assigned to the aromatic $\mathrm{C}-\mathrm{H}$ stretching vibration, while the ${ }^{1} \mathrm{H}$ NMR spectra of poly(BVPC-co-NVP) and poly(BVPB-co-NVP) are similar. As shown in Figure 2c, new proton peaks assigned to the methylene group and phenyl group on the benzyl chloride appeared at $\delta=5.5$ and $7.4 \mathrm{ppm}$.

Besides, ${ }^{13} \mathrm{C}$ NMR and ${ }^{13} \mathrm{C}-{ }^{1} \mathrm{H}$ HSQC were also employed to confirm the structure of poly(BVPC-co-NVP). In the ${ }^{13} \mathrm{C}$ NMR spectrum shown in Figure 3, the peak without coherence contours appeared at the lowest field $\delta=173.1 \mathrm{ppm}$ was attributed to the carbonyl carbon in pyrrolidone. The peaks at $\delta=146.4 \sim 125.8 \mathrm{ppm}$ were assigned to the carbons along the pyridine and benzene rings. In Figure 3 , the ${ }^{13} \mathrm{C}-{ }^{1} \mathrm{H}$ HSQC spectrum revealed the coherence between the chemical shifts of carbon and proton atoms. The coherence contour groups that appeared around $\delta=(128.7,7.5) \mathrm{ppm}$ were assigned to the correlation between the carbons and protons along the benzene ring. Another significant set of cross-peaks at $\delta=(31.8,1.8) \mathrm{ppm}$ appeared due to the strong correlation between the methylene carbons in the backbone and their directly attached protons.

To determine the apparent charge density of quaternary pyridinium-type polymers, colloidal titration method was used. Charge density was calculated using the following formula:

$$
\text { Charge density }(\mathrm{eq} / \mathrm{g})=\frac{c V}{m}
$$

where $c=$ concentration of standard anionic polyelectrolyte solution $(\mathrm{mol} / \mathrm{L}), V=$ volume of PVSK titrated to endpoint (L), and $m=$ amount of cationic copolymer (g).

Based on the result of charge density measurement, the quaterization efficiency of $4 \mathrm{VP}$ can be calculated using the following formula:

$$
\text { Quaternization efficiency }(\%)=\frac{c V}{m} \times \frac{n M_{4 \mathrm{VP}}+(1-n) M_{\mathrm{NVP}}}{n}
$$


where $n=4 \mathrm{VP}$ content in the polymer $(\mathrm{mol} \%)$, data from Table $1, M_{4 \mathrm{VP}}=$ molar mass of $4 \mathrm{VP}(\mathrm{g} / \mathrm{mol})$, and $M_{\mathrm{NVP}}=$ molar mass of NVP $(\mathrm{g} / \mathrm{mol})$.

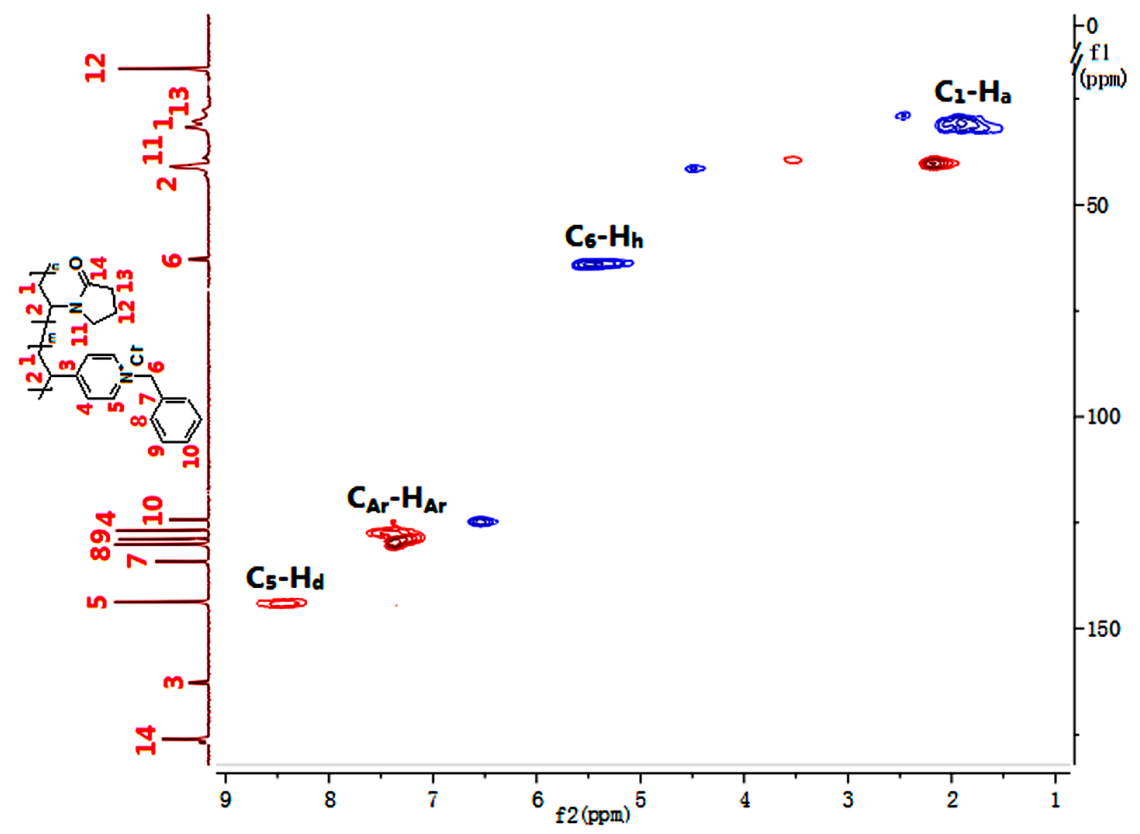

Figure 3. ${ }^{13} \mathrm{C}$ NMR and 2D NMR $\left({ }^{13} \mathrm{C}-{ }^{1} \mathrm{H}\right.$ HSQC NMR) spectra of poly(BVPC-co-NVP) in $\mathrm{D}_{2} \mathrm{O}$.

The results of calculated charge densities, quaternization efficiencies and molecular weights of as-prepared polymers were listed in Table 2. Considering the absorption of polycations onto the GPC (gel permeation chromatography) columns and to obtain the true $M_{\mathrm{w}}$ of polymers, SLS measurements were used to determine the $M_{\mathrm{w}}$ of prepared polymers. Automatically calculated from the intercept of the Debye plots via 90Plus Debye plot analysis software, the quaternized pyridinium homopolymers and copolymers showed $M_{\mathrm{W}} \mathrm{s}$ in the range of 90-100 kDa. The quaternization efficiency of all the copolymers was above $83 \%$, whether the cationic reagent applied was benzyl chloride or benzyl bromide. In comparison, the homopolymer poly(4-vinylpyridine), quaternized by benzyl chloride and benzyl bromide, obtained much lower quaternization efficiency, i.e., $55.4 \%$ and $52.8 \%$, respectively. This result can be interpreted by the steric hindrance caused by the incorporation of benzyl halide component. As a random copolymer, poly(4VP-co-NVP) can be quaternized steadily. Nevertheless, considerable steric hindrance limited the quaternization reaction along the homopolymer, resulting in relatively low quaternization efficiency.

Table 2. Charge density, quaternization efficiency and molecular weight of quaternary pyridinium-type copolymers.

\begin{tabular}{|c|c|c|c|}
\hline Sample & Charge density ${ }^{\text {a }}$ (meq/g) & Quaternization efficiency (\%) & $M_{\mathrm{w}}(\mathrm{kDa})$ \\
\hline PBVPC & 3.16 & 55.4 & 94.5 \\
\hline Poly(BVPC-co-NVP) $)_{1}$ & 2.98 & 92.3 & 92.8 \\
\hline Poly $(\mathrm{BVPC}-\mathrm{co}-\mathrm{NVP})_{2}$ & 2.24 & 97.4 & 96.9 \\
\hline Poly $(\mathrm{BVPC}-\mathrm{co}-\mathrm{NVP})_{3}$ & 0.82 & 90.1 & 93.8 \\
\hline PBVPB & 2.83 & 52.8 & 93.4 \\
\hline Poly(BVPB-co-NVP) ${ }_{1}$ & 2.60 & 90.4 & 98.5 \\
\hline Poly(BVPB-co-NVP) $)_{2}$ & 1.97 & 94.9 & 95.5 \\
\hline Poly(BVPB-co-NVP) $)_{3}$ & 0.75 & 83.1 & 94.4 \\
\hline
\end{tabular}




\subsection{Evaluation of Antimicrobial Activity}

It has been proven that quaternary ammonium salt (QAS) moieties can affect the viability of Gram-positive and Gram-negative bacteria due to positive charges that exert a strong electrostatic interaction with negatively charged bacteria [25-27]. Therefore, the positive charge density of QAS antimicrobial agents plays a key role in their antimicrobial performance. Based on the results of charge density measurements, the MICs of quaternized poly(4VP-co-NVP) were determined against S. aureus and E. coli. Figure 4 shows the results of the in vitro antibacterial activity of the quaternized poly(4VP-co-NVP) with different counter anions as a function of charge density. Both poly(BVPC-co-NVP) and poly(BVPB-co-NVP) exhibited that the MIC value decreased with the increase of positive charge density, indicating enhanced antibacterial activity. Compared with their antibacterial performance against $E$. coli, both poly(BVPC-co-NVP) and poly(BVPB-co-NVP) exhibited much higher antibacterial activity against $S$. aureus, which is related to their different bacterial structures. The peptidoglycan layer in the cell wall of Gram-positive S. aureus, although relatively thick, has a network structure with plenty of pores allowing foreign molecules entrance, while Gram-negative E. coli have another cell membrane outside the peptidoglycan layer, which is composed of lipopolysaccharide and protein [28,29]. The outer cell membrane is a barrier against small foreign molecules. Therefore, Gram-positive bacteria are more receptive to antibiotics than Gram-negative bacteria, due to the absence of the outer member.

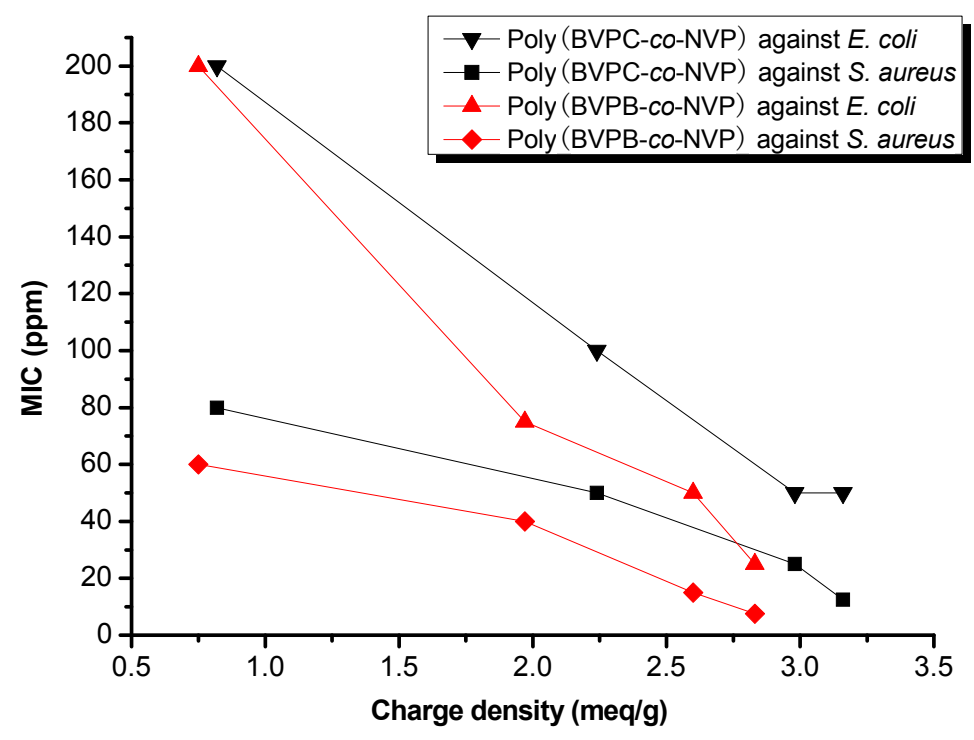

Figure 4. Minimum inhibition concentration of quaternized poly(4VP-co-NVP) against S. aureus and E. coli on the function of charge density.

By comparing the MIC value of polypyridine quaternized by different benzyl halides, it was found that poly(BVPB-co-NVP) presented statistically higher antibacterial activity than poly(BVPC-co-NVP), whether against S. aureus or E. coli. As shown in Figure 4, MIC against E. coli of poly(BVPB-co-NVP) with a charge density of $2.83 \mathrm{meq} / \mathrm{g}$ was $25 \mathrm{ppm}$, while poly(BVPC-co-NVP) exhibited a MIC value of $50 \mathrm{ppm}$ even when the charge density was as high as $3.16 \mathrm{meq} / \mathrm{g}$. Previous research has revealed that the effect of counter anions on the antibacterial activities of QAS is correlated with their steric hindrance and the solubility of the biocides [30,31]. While in the case of polycations with chloride and bromide as the counter anions, both the anions are halides and can dissociate freely in water. Chen et al. [32] and Xie et al. [33] found the same potency difference of biocides as comparing the influence of different haloid anions on their antibacterial performance. Nevertheless, so far no interpretation has been put forward. According to the antibacterial mechanism of polycations, which is elucidated in the following section, the second stage 
of action mode is the displacement of calcium and/or magnesium ions on the cell membrane. If an ammonium ion forms a tight ion-pair with its counter anion via strong coulombian force, it will impede ionic dissociation of QAS, influencing the displacement of those divalent ions. This may explain why poly(BVPB-co-NVP) showed higher antibacterial activity than poly(BVPC-co-NVP).

\subsection{AFM Analysis}

To reveal the antibacterial mechanism of quaternary pyridinium-type copolymer, AFM was applied to observe the morphological alteration of E. coli treated by poly(BVPC-co-NVP). As can been seen from the amplitude and height images of fresh E. coli cells in Figure 5AI,BI, the untreated E. coli maintained biological activity before dehydration, showing cell division. Despite being dehydrated, the fresh cells appeared characteristically compact and intact rods in form, and their edge looked smooth and trim. Therefore, the air drying process prior to AFM observation hardly destroyed the integrity of bacterial cells. To supplement this, the surface rugosity at the top of the bacterial cell was measured for a scan area of $0.2 \times 0.2 \mu \mathrm{m}^{2}$. As marked in Figure 5BI, the scan area shows an Average roughness $R_{\mathrm{a}}$ of $1.24 \mathrm{~nm}$ and a Root Mean Square (RMS) roughness $R_{\mathrm{q}}$ of $1.69 \mathrm{~nm}$. In addition, the cross-section image of fresh E. coli is shown in Figure 5CI. The profile curve corresponding to the line in Figure 5B delineated the high-middle-low-ends oval structure of a fresh cell with the maximum height of $380 \mathrm{~nm}$, and emphasized the smooth texture.

After 3 min of treatment by poly(BVPC-co-NVP) at its MIC concentration, the morphology and structure of E. coli cell became irregular and the surface showed wrinkles, as can be viewed in Figure 5AII. Copious amount of debris with some differently sized micelle-like outer membrane residues emerged around the bacterial cell. The profile curve in Figure 5CII corroborated that grooves and indentations appeared on the cell surface and the maximum height decreased by $180 \mathrm{~nm}$, which was significantly different from the smooth profile curve shown in Figure 5CI. After treatment, the surface roughness of the bacterial cell increased substantially to $11.8 \mathrm{~nm}$ in $R_{\mathrm{a}}$ and $14.5 \mathrm{~nm}$ in $R_{\mathrm{q}}$, respectively. The morphological changes indicated the disruption of the cell membrane, probably due to the binding and interaction of the cationic polymers to the negatively charged lipopolysaccharides in the outer membrane. The bacterial plasma membrane is composed of a phospholipid membrane inner layer and a polysaccharide outer layer, acting as a permeability barrier for most molecules [34]. The negative rest charge of the polysaccharides is neutralized by calcium and/or magnesium ions [35]. It is believed that positively charged QACs preferentially perturb the bacterial wall and membrane by displacing these divalent cations [36,37]. The replacement of the cations destabilizes the bacterial periplasmic components, resulting in the disruption of membrane and leakage of potassium and other metabolites that cause cell death. After exposure to poly(BVPC-co-NVP) for a longer period of time, i.e., $20 \mathrm{~min}$, the morphology of E. coli in Figure 5AIII showed no distinct difference (see Figure 5AII). Similarly, there were many indentations on the surface, and the bacterial cell was fully collapsed and disintegrated. The treated bacterial cell also exhibited a relatively high roughness with $12.8 \mathrm{~nm}$ of $R_{\mathrm{a}}$ and $16.7 \mathrm{~nm}$ of $R_{\mathrm{q}}$. By comparing the cross-section images of treated $E$. coli, the height of bacteria further decreased to below $200 \mathrm{~nm}$ after $20 \mathrm{~min}$ of exposure time. This indicated that $3 \mathrm{~min}$ of exposure to $50 \mathrm{ppm}$ of poly(BVPC-co-NVP) can cause severe damage to E. coli cells, leading to the complete deactivation.

From the AFM observations, it could be concluded that positively charged poly(BVPC-co-NVP) is a highly efficient membrane-active agent which exerts a strong electrostatic interaction with bacteria, and consequently disrupt the cytoplasmic membrane and induce the leakage of the intercellular constituents so as to deactivate the bacteria. 


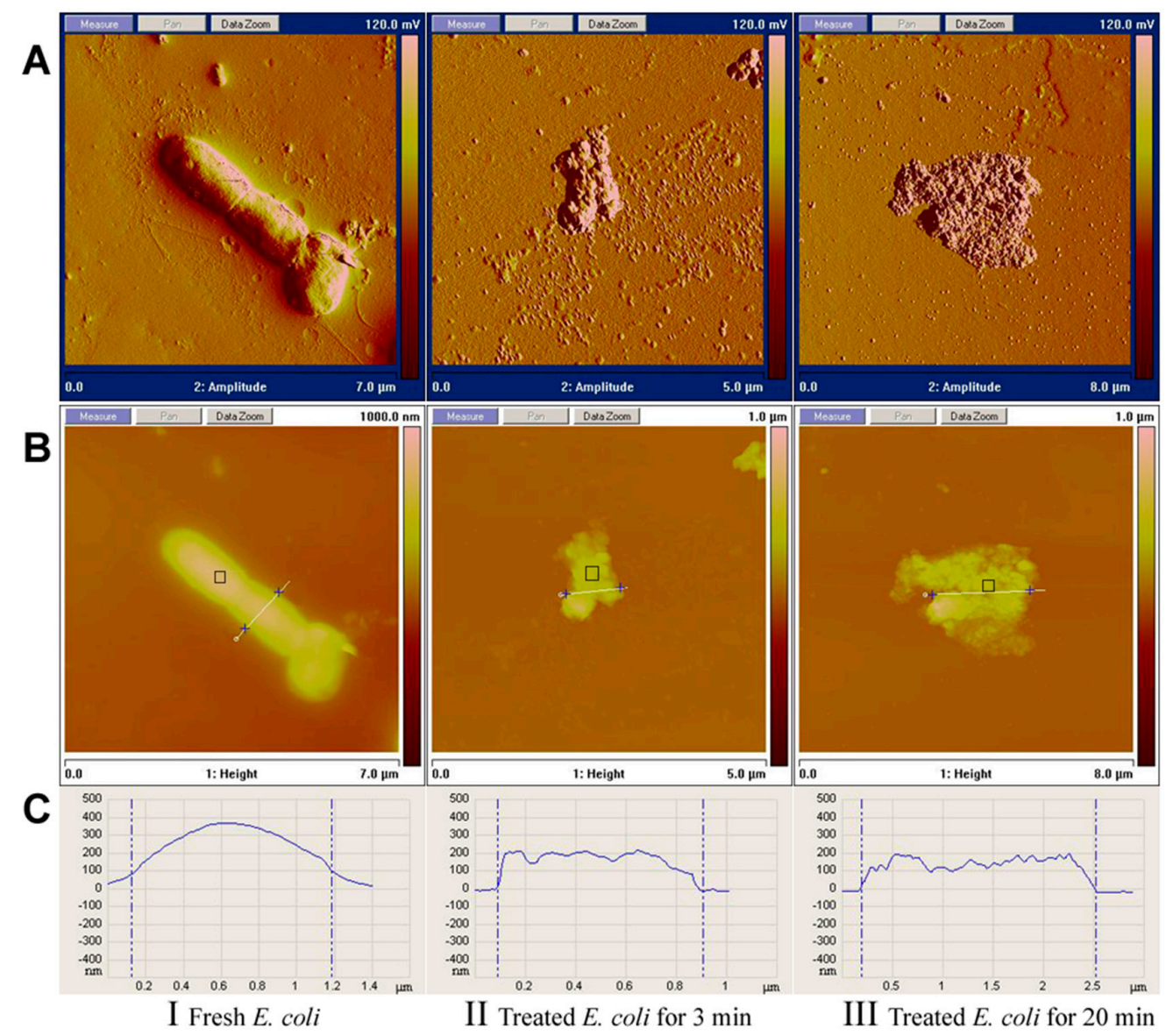

Figure 5. AFM images of morphological alterations of $E$. coli induced by pyridinium-type polycations at different treated times: (A) amplitude image; (B) height image; and (C) cross-section image corresponding to the signal line in (B).

\subsection{Virucidal Assessment}

Enveloped virus, e.g., influenza virus and herpes virus, is protected from outside by a lipid membrane, which typically is derived from portions of the host cell membrane. Functionally, the lipid bilayer envelope facilitates virus to enter host cells and protect them against host immune system [38,39]. It is reasoned that the aforementioned polymeric QAS might penetrate and damage the viral envelope as well, thereby inactivating the virus. To evaluate the antiviral performance of prepared quaternized pyridinium-type copolymers against enveloped virus, influenza virus was selected as the virus model. The plaque assay results in Figure 6 showed that both poly(BVPC-co-NVP) and poly(BVPB-co-NVP) presented virucidal activity, which were positively correlated with the test concentration. At the concentration of their MIC value, i.e., $50 \mathrm{ppm}$, the virucidal efficiencies of poly(BVPC-co-NVP) and poly(BVPB-co-NVP) were $93.3 \%$ and $95.6 \%$, respectively. It was also worth noting that there were no obvious differences in the virucidal efficiency between the two samples at the same concentration, eliminating the possibility of incorporating different counter anions affecting the antiviral performance of prepared polymers. This may reveal that the antiviral activity of polycations depended on the strong interaction between polymer and viral envelope rather than the displacement of ions. Since the viral plaques were revealed by staining surrounded healthy cells, cytotoxicity evaluation of polymer samples was conducted to supplement the antiviral test. Uninfected MDCK cells were treated by polymer samples and further stained using neutral red. Both poly(BVPC-co-NVP) and poly(BVPB-co-NVP) at all the test concentrations, i.e., 10, 25 and $50 \mathrm{ppm}$, had no toxic effect detected. 


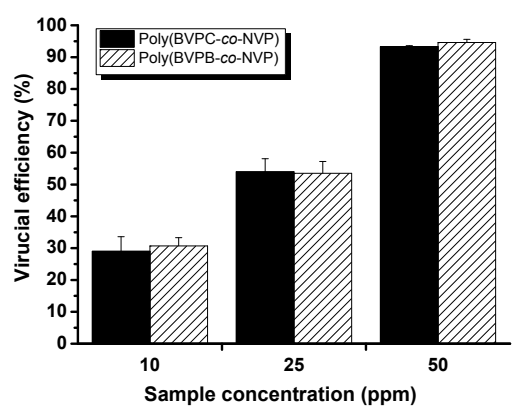

Figure 6. Virucidal efficiency of poly(BVPC-co-NVP) and poly(BVPB-co-NVP) against influenza virus.

The result of plaque assay indicated quaternized pyridinium-type polyvinylpyrrolidone possessed highly antiviral activity against influenza virus. According to the foregoing analysis of structure of enveloped virus, the antiviral mechanism of prepared polymers was deduced to be similar to their antibacterial mechanism. The proposed sequence of events with influenza virus exposed to polycations is schematically illustrated in Figure 7. Polycations adhered to influenza virus via strong adsorption to the lipid envelope surface. Subsequently, disorganization and severe damage of lipid envelope occurred due to the interaction between the polycations and viral particles. This resulted in the leakage of the viral genome and consequent deactivation of the virus.

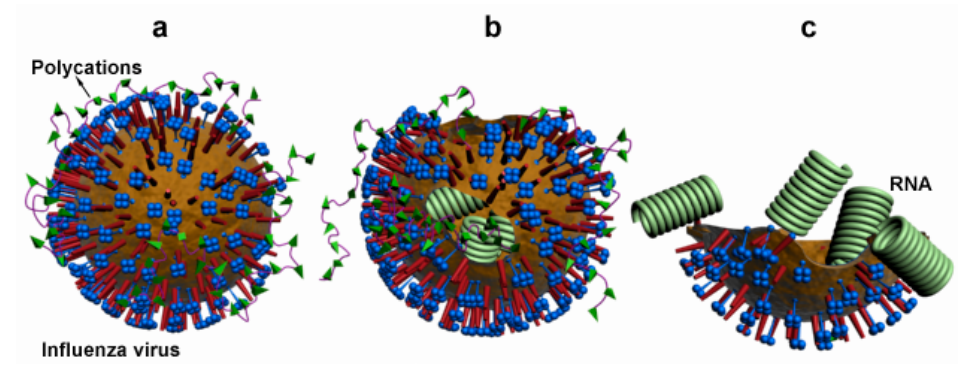

Figure 7. Cartoon depicting the procedure of inactivation of influenza virus by quaternized pyridinium-type polyvinylpyrrolidone: (a) adsorption of polycations onto the surface of viral particle; (b) penetration of polycations into the lipid envelope followed by envelope damage; and (c) leakage of the viral RNA accompanied by virostasis.

\section{Conclusions}

Novel pyridinium-type polyvinylpyrrolidones with two different counter anions were synthesized by a two-step method. FTIR, 2D NMR spectrum, SLS, UV spectrum and charge density measurements confirmed the structure of prepared polycations with controllable compositions. Their antibacterial performance was evaluated against E. coli via MIC test. Results indicated that poly(BVPB-co-NVP) presented higher antibacterial activity than poly(BVPC-co-NVP) due to their difference in ionic dissociation ability. AFM technique was employed to monitor the bacterial inhibition process and showed the pyridinium-type polycations were able to kill E. coli within $3 \mathrm{~min}$. AFM images revealed the polycations deactivated bacteria by disrupting cellular membranes and causing the leakage of intracellular components from bacterial cells. Plaque assay against influenza virus demonstrated that the prepared polycations exhibited antiviral activity with high efficiency, i.e., up to $95.6 \%$ of virucidal efficiency. The novel dual-functional pyridinium-type polyvinylpyrrolidone with both antibacterial and antiviral activities against a broad-spectrum of pathogens are promising for various applications.

Acknowledgments: This study was financially supported by the NSERC strategic network SETINEL-Bioactive Paper (Canada). The authors would also like to thank Tongjun Lin and Adam MacNeil at the Dalhousie University for their help in the antiviral tests. 
Author Contributions: In this study, Yan Xue and Huining Xiao conceived and designed the experiments. Yan Xue performed the experiments, analyzed the data and wrote the paper. Huining Xiao provided the fund and revised the paper.

Conflicts of Interest: The authors declare no conflict of interest.

\section{References}

1. Kenawy, E.; Worley, S.D.; Broughton, R. The chemistry and applications of antimicrobial polymers: A state-of-the-art review. Biomacromolecules 2007, 8, 1359-1384. [CrossRef] [PubMed]

2. Siedenbiedel, F.; Tiller, J.C. Antimicrobial polymers in solution and on surfaces: Overview and functional principles. Polymers 2012, 4, 46-71.

3. Malmsten, M. Antimicrobial and antiviral hydrogel. Soft Matter 2011, 7, 8725-8736. [CrossRef]

4. Huang, J.; Murata, H.; Koepsel, R.R.; Russell, A.J.; Matyjaszewski, K. Antibacterial polypropylene via surface-initiated atom transfer radical polymerization. Biomacromolecules 2007, 8, 1396-1399. [CrossRef] [PubMed]

5. Xue, Y.; Pan, Y.; Xiao, H.; Zhao, Y. Novel quaternary phosphonium-type cationic polyacrylamide and elucidation of dual-functional antibacterial/antiviral activity. RSC Adv. 2014, 4, 46887-46895. [CrossRef]

6. Gong, S.; Epasinghe, D.J.; Zhou, B.; Niu, L.; Kimmerling, K.A.; Rueggeberg, F.A.; Yiu, C.K.Y.; Mao, J.; Pashley, D.H.; Tay, F.R. Effect of water-aging on the antimicrobial activities of an ormosil-containing orthodontic acrylic resin. Acta Biomater. 2013, 9, 6964-6973. [PubMed]

7. Muňoz-Bonilla, A.; Fernández-García, M. Polymeric materials with antimicrobial activity. Prog. Polym. Sci. 2012, 37, 281-339. [CrossRef]

8. Chen, Y.; Wilbon, P.A.; Chen, Y.P.; Zhou, J.; Nagarkatti, M.; Wang, C.; Chu, F.; Decho, A.W.; Tang, C. Amphipathic antibacterial agents using cationic methacrylic polymers with natural rosin as pendant group. RSC Adv. 2012, 2, 10275-10282. [CrossRef]

9. Haldar, J.; An, D.; de Cienfuegos, L.Á.; Chen, J.; Klibanov, A.M. Polymeric coatings that inactivate both influenza virus and pathogenic bacteria. Proc. Natl. Acad. Sci. USA 2006, 103, 17667-17671. [CrossRef] [PubMed]

10. Kawabata, N.; Ujino, I. Removal of virus from air by filtration using a composite microporous membrane made of crosslinked poly(N-benzyl-4-vinylpyridinium chloride). React. Funct. Polym. 1998, 37, 213-218. [CrossRef]

11. Kawabata, N.; Yamazaki, K.; Otake, T.; Oishi, I.; Minekawa, Y. Removal of pathogenic human viruses by insoluble pyridinium-type resin. Epidemiol. Infect. 1990, 105, 633-642. [CrossRef] [PubMed]

12. Kawabata, N. Syntheses of biodegradable vinyl polymers by insertion of $N$-benzyl-4-vinylpyridinium chloride into the main chain. React. Funct. Polym. 2007, 67, 1292-1300. [CrossRef]

13. Cen, L.; Neoh, K.G.; Kang, E.T. Surface functionalization technique for conferring antibacterial properties to polymeric and cellulosic surfaces. Langmuir 2003, 19, 10295-10303. [CrossRef]

14. Yuan, S.J.; Pehkonen, S.O.; Ting, Y.P.; Neoh, K.G.; Kang, E.T. Inorganic-organic hybrid coatings on stainless steel by layer-by-layer deposition and surface-initiated atom-transfer-radical polymerization for combating biocorrosion. ACS Appl. Mater. Interfaces 2009, 1, 640-652. [CrossRef] [PubMed]

15. Krishnan, S.; Ward, R.J.; Hexemer, A.; Sohn, K.E.; Lee, K.L.; Angert, E.R.; Fischer, D.A.; Kramer, E.J.; Ober, C.K. Surfaces of fluorinated pyridinium block copolymers with enhanced antibacterial activity. Langmuir 2006, 22, 11255-11266. [CrossRef] [PubMed]

16. Tiller, J.C.; Liao, C.-J.; Lewis, K.; Klibanov, A.M. Designing surfaces that kill bacteria on contact. Proc. Natl. Acad. Sci. USA 2001, 98, 5981-5985. [CrossRef] [PubMed]

17. Dizman, B.; Elasri, M.O.; Mathias, L.J. Synthesis and characterization of antibacterial and temperature responsive methacrylamide polymers. Macromolecules 2006, 39, 5738-5746. [CrossRef]

18. Eren, T.; Som, A.; Rennie, J.R.; Nelson, C.F.; Urgina, Y.; Nüsslein, K.; Coughlin, E.B.; Tew, G.N. Antibacterial and hemolytic activities of quaternary pyridinium functionalized polynorbornenes. Nat. Rev. Microbiol. 2008, 209, 516-524. [CrossRef]

19. Sambhy, V.; Peterson, B.R.; Sen, A. Antibacterial and hemolytic activities of pyridinium polymers as a function of the spatial relationship between the positive charge and the pendant alkyl tail. Angew. Chem. Int. Ed. 2008, 47, 1250-1254. [CrossRef] [PubMed] 
20. Yu, D.G.; Wang, X.; Li, X.Y.; Chian, W.; Li, Y.; Liao, Y.Z. Electrospun biphasic drug release polyvinylpyrrolidone/ethyl cellulose core/sheath nanofibers. Acta Biomater. 2013, 9, 5665-5672. [CrossRef] [PubMed]

21. Jiang, J.; Zhu, L.; Zhu, L.; Zhang, H.; Zhu, B.; Xu, Y. Antifouling and antimicrobial polymer membranes based on bioinspired polydopamine and strong hydrogen-bonded poly(N-vinyl pyrrolidone). ACS Appl. Mater. Interfaces 2013, 5, 12895-12904. [CrossRef] [PubMed]

22. Gizdavic-Nikolaidis, M.R.; Bennett, J.R.; Swift, S.; Easteal, A.J.; Ambrose, M. Broad spectrum antimicrobial activity of functionalized polyanilines. Acta Biomater. 2011, 7, 4204-4209. [CrossRef] [PubMed]

23. Xu, S.; Xi, X.; Shi, J.; Cao, S. A homogeneous catalyst made of poly(4-vinylpyridine-co- $N$ vinylpyrrolidone)-Pd(0) complex for hydrogenation of aromatic nitro compounds. J. Mol. Catal. A Chem. 2000, 160, 287-292. [CrossRef]

24. Gatica, N.; Gargallo, L.; Radić, D. 2-Vinylpyridine-co- $N$-vinyl-2-pyrrolidone copolymers: Synthesis and reactivity ratios. Polym. Int. 1998, 45, 285-290. [CrossRef]

25. Cheng, L.; Weir, M.D.; Xu, H.H.K.; Antonucci, J.M.; Kraigsley, A.M.; Lin, N.J.; Lin-Gibson, S.; Zhou, X. Antibacterial amorphous calcium phosphate nanocomposites with a quaternary ammonium dimethacrylate and silver nanoparticles. Dent. Mater. 2012, 28, 561-572. [CrossRef] [PubMed]

26. Ye, S.; Majumdar, P.; Chisholm, B.; Stafslien, S.; Chen, Z. Antifouling and antimicrobial mechanism of tethered quaternary ammonium salts in a cross-linked poly(dimethylsiloxane) matrix studied using sum frequency generation vibrational spectroscopy. Langmuir 2010, 26, 16455-16462. [CrossRef] [PubMed]

27. Shalev, T.; Gopin, A.; Bauer, M.; Stark, R.W.; Rahimipour, S. Non-leaching antimicrobial surfaces through polydopamine bio-inspired coating of quaternary ammonium salts or an ultrashort antimicrobial lipopeptide. J. Mater. Chem. 2012, 22, 2026-2032. [CrossRef]

28. Wang, Y.; Zhou, Z.; Zhu, J.; Tang, Y.; Canady, T.D.; Chi, E.Y.; Schanze, K.S.; Whitten, D.G. Dark antimicrobial mechanisms of cationic phenylene ethynylene polymers and oligomers against Escherichia coli. Polymers 2011, 3, 1199-1214. [CrossRef]

29. Xue, Y.; Guan, Y.; Zheng, A.; Wang, H.; Xiao, H. Synthesis and characterization of ciprofloxacin pendant antibacterial cationic polymers. J. Biomat. Sci. Polym. Ed. 2012, 23, 1115-1128. [CrossRef] [PubMed]

30. Luczak, J.; Jungnickel, C.; Lacka, I.; Stolte, S.; Hupka, J. Antimicrobial and surface activity of 1-alkyl-3-methylimidazolium derivatives. Green Chem. 2010, 12, 593-601. [CrossRef]

31. Yudovin-Farber, I.; Beyth, N.; Weiss, E.I.; Domb, A.J. Antibacterial effect of composite resins containing quaternary ammonium polyethyleneimine nanoparticles. J. Nanopart. Res. 2010, 12, 591-603. [CrossRef]

32. Chen, C.Z.; Beck-Tan, N.C.; Dhurjati, P.; van Dyk, T.K.; LaRossa, R.A.; Cooper, S.L. Quaternary ammonium functionalized poly(propylene imine) dendrimers as effective antimicrobials: Structure-activity studies. Biomacromolecules 2000, 1, 473-480. [CrossRef] [PubMed]

33. Xie, D.; Weng, Y.; Guo, X.; Zhao, J.; Gregory, R.L.; Zheng, C. Preparation and evaluation of a novel glass-ionomer cement with antibacterial functions. Dent. Mater. 2011, 27, 487-496. [CrossRef] [PubMed]

34. Ruiz, N.; Kahne, D.; Silhavy, T.J. Advances in understanding bacterial outer-membrane biogenesis. Nat. Rev. Microbiol. 2006, 4, 57-66. [PubMed]

35. Zasloff, M. Antimicrobial peptides of multicellular organisms. Nature 2002, 415, 389-395. [CrossRef] [PubMed]

36. Murata, H.; Koepsel, R.R.; Matyjaszewski, K.; Russell, A.J. Permanent, non-leaching antibacterial surface 2: How high density cationic surfaces kill bacterial cells. Biomaterials 2007, 28, 4870-4879. [CrossRef] [PubMed]

37. Asri, L.A.T.W.; Crismaru, M.; Roest, S.; Chen, Y.; Ivashenko, O.; Rudolf, P.; Tiller, J.C.; van der Mei, H.C.; Loontjens, T.J.A.; Busscher, H.J. A shape-adaptive, antibacterial-coating of immobilized quaternary-ammonium compounds tethered on hyperbranched polyurea and its mechanism of action. Adv. Funct. Mater. 2014, 24, 346-355. [CrossRef]

38. Harrison, S.C. Viral membrane fusion. Nat. Struct. Mol. Biol. 2008, 15, 690-698. [CrossRef] [PubMed]

39. Smith, A.E.; Helenius, A. How viruses enter animal cells. Science 2004, 304, 237-242. [CrossRef] [PubMed]

(C) 2015 by the authors; licensee MDPI, Basel, Switzerland. This article is an open access article distributed under the terms and conditions of the Creative Commons by Attribution (CC-BY) license (http://creativecommons.org/licenses/by/4.0/). 